\title{
Pengaruh Sikap Ilmiah SisWa Terhadap Hasil Belajar Materi BANGUN RUANG SISWA KELAS VIII SMP NEgERI 3 MINASATENE
}

\author{
THE EFFECT OF STUDENTS' SCIENTIFIC ATTITUDE IN LEARNING RESULTS OF \\ STUDENTS' GEOMETRY Class VIII SMP NEgERI 3 MinaSATANE
}

\author{
Firdha Razak ${ }^{1}$ dan Rahmat Kamaruddin ${ }^{2}$ \\ 1 Pendidikan Matematika, STKIP Andi Matappa Pangkep \\ Jl. Andi Mauraga No 70, Kabupaten Pangkajene Kepulauan, Sulawesi Selatan, Indonesia \\ firdarazak@yahoo.com \\ 2 Pendidikan Matematika, STKIP Andi Matappa Pangkep \\ Jl. Andi Mauraga No 70, Kabupaten Pangkajene Kepulauan, Sulawesi Selatan, Indonesia
}

\begin{abstract}
Abstrak
Matematika adalah pelajaran yang kurang diminati oleh siswa, dalam belajar lebih banyak siswa pasif, sehingga sikap ilmiah siswa kurang berkembang, sehingga hasil belajar siswa cenderung menurun. Sehingga guru matematika selalu berusaha mengembangkan metode pembelajaran untuk meningkatkan sikap ilmiah siswa, yang berdampak pada hasil belajar siswa. Pernyataan tersebut menarik peneliti untuk mengambil isu studi kelas VIII SMP Negeri 3 Minasatene. Populasi yang diambil adalah kelas VIII SMP Negeri 3 Minasatene, dengan sampel penelitian kelas VIIIA sebanyak 27 siswa. Teknik pengumpulan data sikap ilmiah dengan menggunakan kuesioner dan lembar observasi sedangkan hasil belajar dengan menggunakan uji. Analisis data menggunakan regresi linier sederhana. Signifikansi koefisien regresi dan model regresi kelinearan didapatkan pengaruh sikap ilmiah $(\mathrm{X})$ terhadap hasil belajar $(\mathrm{Y})$, menurut persamaan regresi $\mathrm{Y}=$ $0,0109+0.138 X$. Untuk menguji koefisien signifikansi regresi yang diperoleh t hitung 5.197 diatas tabel 2.02 maka Ho ditolak yang berarti koefisien regresi signifikan. Uji kelinearan diperoleh Fhitung 26,801 di atas Ftabel 4,08, dan signifikan $0,00<0,05$, maka Ho ditolak yang berarti pada hubungan linier dari sikap ilmiah dan hasil belajar. Sehingga dapat disimpulkan ada pengaruh sikap ilmiah terhadap hasil belajar siswa kelas VIII SMP Negeri 3 Minasatene.

Kata Kunci: Sikap Ilmiah, Hasil Belajar.
\end{abstract}

\section{Abstract}

Mathematics is a lesson that is less interested by students, in learning more passive students, so that students' scientific attitude is less developed, resulting in student learning outcomes that tend to decline. So that the math teacher always tries to develop the learning method to improve the students' scientific attitude, which impact on student learning outcomes. The statement attracted researchers to take the issue is the influence of scientific attitudes toward the results of student learning VIII grade SMP Negeri 3 Minasatene. Population taken is class VIII SMP Negeri 3 Minasatene, with research sample class VIIIA counted 27 students. Technique of collecting scientific attitude data by using questionnaire and observation sheet while study result by using test. Data analysis using simple linear regression. The significance of regression coefficient and linearity regression model got the influence of scientific attitude $(X)$ on learning result $(Y)$, according to regression equation $Y=0,0109+0,138 X$. To test the coefficient significance regression obtained $t$ arithmetic 5,177 above table is 2.02 then Ho rejected which means significant regression coefficient. Linearity test obtained Fcount 26,801 above Ftabel 4,08, and significant $0,00<0,05$, hence Ho is rejected which means on linear relationship of scientific attitude and learning result. So it can be concluded there is influence of scientific attitude toward student learning result of class VIII SMP Negeri 3 Minasatene.

Keyword: Scientific Attitude, Learning Outcome.

Jurnal "Mosharafa", Volume 7, Nomor 1, Januari 2018 


\section{Pendahuluan}

Matematika merupakan dasar dari pelajaran-pelajaran yang lain, seperti ekonomi, bahasa Indonesia, sejarah, olahraga, dan lain-lain. Hal ini dikarenakan dalam penerapaannya, pelajaran-pelajaran tersebut sering menggunakan unsur matematika, seperti bilangan, nilai hitung, dan sebagainya. Namun, pandangan siswa secara umum mengenai pelajaran matematika, bahwa matematika merupakan pelajaran yang susah dimengerti dan kurang diamati, dikarenakan anggapan siswa terhadap pelajaran matematika dengan rumus yang cukup beragam dan rumit, serta kurangnya rasa keingintahuan dan kurang kritisnya siswa dalam mempelajari matematika. Ini mengakibatkan siswa kurang pasif dalam belajar matematika. Kurangnya rasa ingin tahu dan kekritisan yang terdapat dalam diri siswa, dan kecenderungan siswa belajar hanya dengan menghafal rumus saja tanpa mengetahui dari mana rumus tersebut diperoleh, serta sikap siswa yang terkadang kurang jujur dalam belajar, ini kurang bisa mendorong sikap ilmiah siswa kearah positif yang berakibat hasil belajar siswa yang cenderung menurun begitu pula di SMP Negeri 3 Minasatene. Terkadang sikap ilmiah siswa menunjukkan kurang kearah positif sehingga guru matematika sekolah berusaha untuk mengembangkan metode pembelajaran guna meningkatkan sikap ilmiah siswa.

Berdasarkan informasi guru matematika di kelas VIII SMP Negeri 3
Minasatene, bahwa permasalahan kurang minat belajar siswa masih sering terjadi. Sikap ilmiah siswa masih menunjukkan kurang kearah positif seperti siswa terkadang masih menunggu perintah guru, kurang disertai rasa keingintahuan, dan kekritisan siswa dalam belajar matematika. Siswapun terkadang kurang jujur kepada guru, sehingga kurang adanya keluwesan dalam kegiatan belajar. Hasil belajar yang diperoleh siswa masih kurang dengan nilai rata-ratanya adalah 64 .

Dari latar belakang inilah penulis perlukan mengadakan penelitian di SMP Negeri 3 Minasatene yang didalamnya meneliti tentang pengaruh sikap ilmiah siswa terhadap hasil belajar pada meteri bangun ruang kelas VIII SMP Negeri 3 Minasatene.

Beberapa ahli memberikan batasan definisi tentang belajar. Menurut Daryanto dalam bukunya Belajar dan Mengajar (2010:2) "belajar adalah suatu proses usaha yang dilakukan seseorang untuk memperoleh suatu perubahan tingkah laku yang baru secara keseluruhan, sebagai hasil pengalamannya sendiri dalam interaksi dengan lingkungannya".

Menurut Aunurrahman dalam bukunya Belajar dan Pembelajaran berpendapat bahwa "belajar merupakan suatu aktivitas pada diri seseorang yang disadari atau disengaja, bagian dari proses untuk memaksimalkan bakat yang dimiliki seseorang".

Selanjutnya, menurut Isriani Handini dalam bukunya Strategi Belajar Pembelajaran Terpadu (2012: 4) "belajar 
pada dasarnya berbicara tentang tingkah laku seseorang berubah sebagi akibat pengalaman yang berasal dari lingkungan".

Dari beberapa pendapat para ahli tentang pengertian belajar disimpulkan bahwa belajar merupakan suatu proses perubahan tingkah laku untuk memperoleh kepandaian dari suatu yang dikerjakan.

Belajar pada setiap akhir pembelajaran. Nilai yang diperoleh siswa menjadi acuan untuk melihat penguasaan siswa dalam menerima materi pelajaran".

Hasil belajar merupakan kemapuan yang dimiliki seseorang sebagai proses belajar, ataupun merupakan penguasaan pengetahuan keterampilan yang dikembangkan oleh mata pelalajaran, yang biasanya ditunjukkan adalah nilai tes matematika yang diberikan guru sebagai hasil penguasaan pengetahuan dan keterampilan.

Menurut psikologi pendidikan yaitu Gagne dalam bukunya Condition Learning yang dikutip Miftahul Huda (2011:15), bahwa kondisi belajar sangat mempengaruhi perbuatan belajar, diantaranya:

a. Kondisi belajar intern

1. Kematangan belajar

2. Belajar untuk belajar

3. Kemampuan belajar

4. Kumpulan presepsi dan pengertian dasar

b. Kondisi belajar ekstern

1. Kontinguitas

2. Latihan

3. Penguatan
Sedangkan menurut Mudzakkir, yang dikutip oleh Ahmad dan Joko Sutrisno (2006: 115) berpendapat mengenai faktorfaktor penyebab kesulitan belajar digolongkan menjadi dua, yaitu:

a. Faktor Intern (faktor dari dalam diri manusia) meliputi:

1. Faktor fisiologi

2. Faktor psikologi

b. Faktor Ekstern (faktor dari luar diri manusia) meliputi:

1. Faktor-faktor non social

2. Faktor-faktor social

Menurut Gagne "sikap adalah suatu kondisi internal. Sikap mempengaruhi pilihan untuk bertindak. Kecenderungan untuk memilik obyek terdapat pada diri pembelajar, bukan kinerja spesifik."

Sikap dalam hal ini adalah suatu kombinasi, informasi, dan emosi yang dihasilkan di dalam predisposisi untuk merespon orang, kelompok, gagasan, peristiwa, atau obyek tertentu secara menyenangkan atau tidak menyenangkan.

Sikap ilmiah adalah suatu sikap yang menerima pendapat orang lain dengan baik dan benar yang tidak mengenal putus asa serta dengan ketekunan juga dengan keterbukaan.

Orang yang berkecimpun dalam ilmu alamiah akan terbentuk sikap ilmiah yang antara lain adalah: (1) jujur, (2) terbuka, (3) toleran, (4). Skeptic, (5) optimis, (6) pemberani, dan (7) kreatif.

Sikap ilmiah adalah suatu sikap yang menerima pendapat orang lain dengan baik dan benar yang tidak mengenal putus asa serta dengan ketekunan juga 
keterbukaan. Sikap ilmiah merupakan sikap yang harus ada pada diri seseorang ilmuwan atau akademisi ketika menghadapi persoalan-persoalan ilmiah untuk dapat melalui proses penelitian yang baik dan hasil yang baik pula. Rumusan di atas diartikan bahwa sikap mengandung tiga komponen yaitu komponen kognitif, komponen afektif dan komponen psikomotorik sikap selalu berkenaan dengan suatu objek dan sikap terhadap objek ini disertai dengan perasaan positif atau negatif.

Secara umum dapat disimpulkan bahwa sikap adalah suatu kesiapan yang senantiasa cenderung untuk berperilaku atau bereaksi dengan cara tertentu bilamana dihadapkan dengan suatu masalah atau objek.

\section{Metode}

Penelitian ini dilaksanakan di SMP Negeri 3 Minasatene yang dilaksanan pada semester ganjil. Pada tanggal 5 April - 8 April. Subjek penelitian ini adalah siswa kelas VIII-A SMP Negeri 3 Minasatene yang berjumlaah 27 orang.

Jenis penelitian ini adalah Eksperimen, yang bertujuan untuk mengetahui apakah ada pengaruh sikap ilmiah terhadap hasil belajar siswa. Pendekatan yang digunakan dalam penelitian ini adalah pendekatan kuantitatif, karena peneliti ingin mendapatkan informasi lebih mendalam berupa data-data numerik terhadap hasil penelitian yang dilakukan kemudian menguraikan kesimpulan yang didapat setelah penelitian.
Dalam hal ini variabel bebas $(X)$ adalah sikap ilmiah siswa SMP kelas VIII, sedangkan variabel terikat (Y) adalah hasil belajar SMP kelas VIII pada mata pelajaran matematika materi bangun ruang.

Adapun desain penelitiannya adalah sebagai berikut:

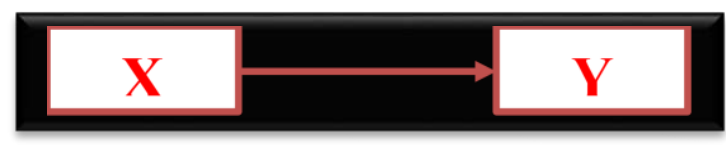

Gambar 1. Bagan Desain Penelitian.

Keterangan:

X: Pembelajaran sikap ilmiah siswa terhadap hasil belajar pada materi bangun ruang

Y: Hasil belajar siswa

Populasi penelitian ini adalah siswa kelas VIII di SMP Negeri 3 Minasatene pada tahun ajaran 2016/2017, yang berjumlah 54 orang siswa, yang terdiri dari kelas VIII A 27 orang dan kelas B 27 Orang.

Sampel diambil dari populasi dengan teknik random sampling. Hal ini dilakukan karena didalam SMP Negeri 3 Minasatene tidak mengenal kelas unggulan atau favorit, maka setiapa unit populasi berpeluang sama untuk dipilih. Data diasumsikan homogen. Peneliti mengambil sampel untuk kelas ujicoba satu kelas, sebanyak 27 siswa, yaitu kelas $B$.

Untuk memperoleh data mengenai sikap ilmiah siswa peneliti mengambil data melalui observasi dan angket. Peneliti menggunakan dua cara tersebut agar kelemahan antara angket dan observasi saling menutupi untuk memperoleh data yang lebih baik. 
Hasil belajar matematika tentang materi bangun ruang yang diukur dengan menggunakan tes.

Ada beberapa prosedur dalam penelitian ini, yaitu:

1. Perencanaan, meliputi perumusan tujuan, penentuan variabel.

2. Penulisan butir soal, atau item kuesioner, penyusunan skala.

3. Penyuntingan, melengkapi dengan pedoman mengerjakan, surat pengantar, kunci jawaban, dan lainlain yang diperlukan.

4. Uji coba penganalisaan hasil, analisis item, melihat pola jawaban, peninjauan saran-saran.

Fase penskoran angket dan observasi peneliti menggunakan interval 1-5. Khusus untuk angket di dalam penskorannya antara positif dan negatif berbeda, untuk aturan yang positif penskoran multiplecoicenya adalah : a (1), b (2), c (3), d (4), e (5), sedangkan untuk aturan yang negatif penskoran multiplecoicenya adalah : a (5), b(4), c(3), d (2), dan e (1).

Lembar observasi di dalam penskorannya berbeda dengan angket sesuai dengan sistem penilaiannya. Untuk item menurut Arifin penilaian a (5) sangat sesuai, b (4) sesuai, c (3) cukup sesuai, d (2) kurang sesuai, e (1) tidak sesuai. Skor sikap ilmiah siswa dapat diperoleh dengan jumlah skor angket ditambah dengan skor angket dibagi dua.

Berikut tabel Kriteria Penentuan Hasil Observasi:

Tabel 1.

Kriteria Penentuan Hasil Observasi

\begin{tabular}{|ccc|}
\hline Skor & Nilai & Kriteria \\
\hline A & 5 & Sangat Sesuai \\
\hline B & 4 & Sesuai \\
\hline C & 3 & Cukup Sesuai \\
\hline D & 2 & Kurang Sesuai \\
\hline E & 1 & Tidak Sesuai \\
\hline
\end{tabular}

Teknik analisis data menggunakan bantuan software statistik yaitu Statistical Product and Service Solution (SPSS).

a. Uji Normalitas

Sebelum mengadakan penelitian, peneliti terlebih dahulu menguji Normalitas. Uji normalitas ini dilakukan agar pengujian hipotesis dan pembuatan selang kepercayaan dapat dilakukan. Untuk Normalitas peneliti menggunakan chi-kuadrat, dengan rumus sebagai berikut:

$$
X^{2}=\sum_{i=1}^{k}\left(S \frac{i O-i E}{E l}\right)
$$

Keterangan:

$\mathrm{X}^{2} \quad=$ harga Chi-kuadrat

${ }_{\mathrm{O}}=$ frekuensi hasil pengamatan

$\mathrm{i}$ = frekuensi yang diharapkan

Perhitungan ini dikonsultasikan dengan $X_{2 t a b e l}$ jika harga $X_{2 h i t u n g} X_{2} \leq X_{2 \text { tabel }}$ dengan taraf signifikan $5 \%$ berarti berasal dari populasi yang berdistribusi normal.

b. Analisis Regresi

Analisis Regresi dilakukan untuk mengetahui hubungan antara variabel terikat $(Y)$ dengan variabel bebas $(X)$, maka untuk mengetahui adakah pengaruh antara sikap ilmiah terhadap hasil belajar, dalam hal ini peneliti menggunakan regresi linier sederhana. Pengolahan data diatas menggunakan program SPSS. Model persamaan regresi linier sederhana adalah: 


$$
Y^{\wedge}=a+B x
$$

Keterangan:

$\mathrm{Y}=$ hasil belajar siswa kelas VIII SMP

Negeri 3 Minasatene

$\mathrm{X}=$ sikap ilmiah siswa kelas VIII SMP

Negeri3 Minasatene

c. Uji Korelasi

Uji korelasi ini digunakan untuk mengetahui apakah kedua variabel (sikap ilmiah dan hasil belajar) ada hubungan atau tidak.

Hipotesis:

Ho: Tidak ada hubungan antara sikap ilmiah dengan hasil belajar siswa kelas VIII SMP Negeri 3 Minasatene.

Ha: ada hubungan antara sikap ilmiah dengan hasil belajar siswa kelas VIII SMP Negeri Minasatene.

Untuk mengetahui apakah dua variabel ada hubungan yang independen atau tidak, maka diperlukan pengujian independen, dan hipotesis yang harus diuji adalah:

$\mathrm{Ho}=\mathrm{P}=\mathrm{O}$

$\mathrm{Ho}=\mathrm{P} \neq \mathrm{O}$

taraf kepercayaan yang dipakai adalah $\alpha=$ $5 \%$.

Untuk pengujian diatas, jika sampel acak berdistribusi normal bervariabel dua itu berukuran $\mathrm{n}$ dan memiliki korelasi $r$, maka menggunakan statistik t.

\section{Hasil dan Pembahasan}

\section{A. Hasil Penelitian}

Pada bagian ini akan dibahas hasil penelitian mengenai pengaruh sikap ilmiah siswa terhadap hasil belajar materi bangun ruang siswa kelas VIII SMP Negeri 3 Minasatene dengan menguji normalitas.

Dengan taraf kepercayaan 5\%, diuji dengan menggunakan perbandingan statistik 2 dengan 2 hitung tabel $X X$. Dari perhitungan melalui SPSS diperoleh bahwa $2=10,476$ hitung $X$ dan $2=41,337$ tabel $X$. Berdasarkan kriteria jika 22 hitung tabel $X$ < X, maka Ho diterima, jadi dapat diperoleh kesimpulan bahwa data berasal dari distribusi normal, hal tersebut juga ditunjukkan dalam signifikansinya yang menunjukkan 0,999, yang mana lebih dari 0,05 .

Setelah data uji normalitas, selanjutnya dianalisis menggunakan analisis regresi linier sederhana. Adapun data hasil penelitian untuk penguasaan sikap ilmiah $(X)$ dan kemampuan menyelesaikan soal bangun ruang $(Y)$ adalah sebagai berikut:

Tabel 2.

Daftar Nilai Akhir Pengaruh Sikap IImiah (X) Dan Bangun Ruang $(\mathrm{Y})$

\begin{tabular}{|cccc|}
\hline No & Kode & $\mathbf{X}$ & $\mathbf{Y}$ \\
\hline 1 & A-1 & 82 & 77 \\
\hline 2 & A-2 & 75 & 75 \\
\hline 3 & A-3 & 80 & 75 \\
\hline 4 & A-4 & 75 & 80 \\
\hline 5 & A-5 & 80 & 87 \\
\hline 6 & A-6 & 95 & 85 \\
\hline 7 & A-7 & 75 & 75 \\
\hline 8 & A-8 & 90 & 80 \\
\hline 9 & A-9 & 80 & 90 \\
\hline 10 & A-10 & 80 & 80 \\
\hline 11 & A-11 & 80 & 85 \\
\hline 12 & A-12 & 85 & 75 \\
\hline 13 & A-13 & 85 & 75 \\
\hline 14 & A-14 & 85 & 80 \\
\hline 15 & A-15 & 80 & 80 \\
\hline 16 & A-16 & 90 & 90 \\
\hline 17 & A-17 & 80 & 75 \\
\hline 18 & A-18 & 75 & 80 \\
\hline 19 & A-19 & 80 & 70 \\
\hline
\end{tabular}




\begin{tabular}{|llll|}
\hline 20 & A-20 & 75 & 80 \\
\hline 21 & A-21 & 80 & 80 \\
\hline 22 & A-22 & 85 & 75 \\
\hline 23 & A-23 & 75 & 70 \\
\hline 24 & A-24 & 80 & 75 \\
\hline 25 & A-25 & 85 & 75 \\
\hline 26 & A-26 & 85 & 75 \\
\hline 27 & A-27 & 85 & 85 \\
\hline
\end{tabular}

Beberapa langkah yang dilakukan dalam analisis regresi linier sederhana ini, yaitu sebagai berikut:

1. Menentukan Persamaan Regresi Linier Sederhana.

Adapun hasil analisis regresi linier sederhana nilai akhir penguasaan konsep sikap ilmiah $(X)$ dan kemampuan menyelesaikan soal bangun ruang $(Y)$ adalah sebagai berikut:

$$
Y=2.497+0,94 X
$$

Dari persamaan regresi diatas, dapat diartikan bahwa jika nilai penguasaan konsep operasi bentuk aljabar bertambah 1, maka nilai kemampuan menyelesaikan soal bangun ruang akan bertambah 0,94. Sedangkan apabila tidak memiliki penguasaan konsep sikap ilmiah, maka kemampuan menyelesaikan soal bangun ruang akan bertambah 2,497.

\section{Statistik Deskriptif}

Di dalam anailis regresi perhitungannya menggunakan SPSS, dengan sampel sebanyak 27 siswa, diperoleh rata-rata skor sikap ilmiah siswa 81,37 dengan simpangan baku untuk sikap ilmiah siswa 1,13999. Rata-rata hasil belajar adalah 78, sedangkan simpangan baku hasil belajar adalah 78, sedangkan simpangan baku hasil belajar adalah 6,63601. Dalam hal ini menujukkan bahwa 40,1\% hasil belajar siswa dipengaruhi oleh sikap ilmiah, dengan sisanya 59,9 \% dipengaruhi oleh sebab-sebab lain.

\section{Uji Koefisien Korelasi}

Perhitungan korelasi antara sikap ilmiah dan hasil belajar diperoleh hasil koefisien korelasinya adalah 0,633-1,00. Hal ini menunjukkan hubungan cukup kuat diantara sikap ilmiah siswa dan hasil belajar siswa kelas VIII SMP Negeri 3 Minasatene. Arah hubungan yang diperoleh adalah positif (tidak ada tanda negatif pada angka 0,633) yang menunjukkan semakin besar sikap ilmiah yang dimiliki siswa semakin meningkat pula hasil belajar siswa yang diperoleh.

Demikian untuk sebaliknya, pengujian statistik yang menggunakan koefisien korelasi dalam menentukan ada atau tidaknya hubungan antara sikap ilmiah dan hasil belajar siswa untuk $t$ hitungnya diperoleh 5,177, sedangkan $t$ tabelnya 2,02 . Disini terlihat jelas bahwa $t$ tabel nilainya kurang dari t hitungnya, begitu pula tingkat signifikan koefisien korelasi adalah 0,0 jauh dibawah taraf kepercayaan yaitu 0.05. dari perhitungan perbandingan statistik hitungnya dan tingkat signifikan koefisien korelasinya menunjukkan bahwa hipotesis diterima, yang artinya ada hubungan antara sikap ilmiah siswa dengan hasil belajar kelas VIII SMP Negeri 3 Minasatene.

\section{Uji Keberartian Koefisien Regresi}

Dari perhitungan SPSS inidapat dilihat koefisiennya menyatakan bahwa nilai $B$ konstanta 0,94 yang menyatakan bahwa jika sikap ilmiah siswa diabaikan, maka 
rata-rata hasil belajar siswa adalah 0,138. Nilai B sikap ilmiah siswa menunjukkan 0,94 dimana menyatakan bahwa setiap skor sikap ilmiah siswa meningkat I, maka rata-rata hasil belajar siswa akan meningkat 0,94. Untuk menguji keberartian koefisien regresi dalam perhitungan SPSS menggunakan statistik t. hipotesis pengujian sebagai berikut:

Ho: Koefisien regresi tidak berarti (signifikan)

$\mathrm{H1}$ : Koefisien regresi berarti (signifikan)

Taraf pengambilan kepercayaan adalah $5 \%$. Dengan pengambilan keputusan membandingkan statistik thitung dengan statistik tabel.

Perhitungan koefisien konstanta, diperoleh $t$ hitung 5, 177, pada derajat kebebasan $\mathrm{N}-2=27-2=25$, dengan tingkat signifikan kepercayaan adalah 5\% sehingga diperoleh t tabelnya adalah 2,02. Sedangkan berdasarkan probabilitasnya diperoleh bahwa perhitungan signifikannya adalah 0,000. Oleh dikarenakan t hitung konstanta lebih dari t tabel, dan probabilitasnya jauh dibawah 0,05, maka Ho diterima yang artinya koefisien regresi signifikan untuk konstantanya.

\section{Uji Kelinieran Model Regresi}

Melalui perhitungan dengan SPSS diperoleh hasil jumlah kuadrat regresinya adalah 21,336, sedangkan jumlah kuadrat sisanya adalah 31,843 . Sehingga jumlah kuadrat totalnya adalah 53,179, rataan kuadrat regresinya adalah 21,336, dan rataan kuadrat residunya adalah 0,79655.
Selanjutnya untuk mencari uji kelinieran regresi menggunakan tingkat kepercayaan 5\% dengan menggunakan statistik Kriteria Penolakan, yang dari perhitungannya terlihat bahwa $\mathrm{F}$ hitung nilainya lebih dari F tabel $(26,801>4,04)$ serta signifikansi dibawah 0,05 $(0,00<0,05)$, maka Hipotesis ditolak, yang artinya terdapat hubungan secara linier antara sikap ilmiah siswa dengan hasil belajar.

\section{B. Pembahasan}

Penelitian yang dilakukan peneliti untuk mengetahui adakah pengaruh sikap ilmiah siswa terhadap hasil belajar siswa kelas VIII SMP Negeri 3 Minasatene yang telah diuji keberartian, model regresinya dan korelasinya menunjukkan bahwa ada pengaruh sikap ilmiah siswa dengan hasil belajar dari siswa kelas VIII. Pengaruh yang terjadi antara sikap ilmiah dengan hasil belajar ini menunjukkan bahwa ada pengaruh yang terjadi antara sikap ilmiah dengan hasil belajar ini menunjukkan pengaruh yang cukup kuat dengan saling mempengaruhi, dimana sikap ilmiah siswa mempengaruhi hasil belajar, ataupun sebaliknya. Jadi semakin tinggi sikap ilmiah siswa semakin tinggi pula hasil belajar siswa. Begitu pula sebaliknya semakin rendah sikap ilmiah siswa hasil belajar siswa semakin menurun pula.

Besarnya pengaruh sikap ilmiah terhadap hasil belajar dapat dilihat dari koefisien korelasinya dan R2 sebesar 40\% sikap ilmiah mempengaruhi hasil belajar, sedang 60\% lainnya adalah komponen pendukung lainnya, khususnya dalam 
mata pelajaran matematika. Hal tersebut dapat terjadi, dikarenakan sikap ilmiah yang terdapat pada diri siswa merupakan sikap yang tidak dipaksakan seseorang untuk bertindak dalam mempelajari sesuatu melainkan muncul dari diri siswa itu sendiri, sehingga mendorong siswa untuk mencapai tujuan belajar yaitu hasil yang tinggi dan maksimal.

Sikap ilmiah siswa yang berasal dari keingintahuan siswa, kejujuran siswa, serta sikap kekritisan dalam mempelajari suatu pelajaran, khususnya pelajaran matematika menjadikan siswa dalam belajar matematika akan bersungguhsungguh tanpa ada paksaan dari pihak lain. Karena sikap ilmiah siswa inilah yang menjadikan siswa akan menyenangi pelajaran, sehingga hasil belajar yang diperoleh siswa akan baik. Jadi dalam hal ini belajar matematika, seorang guru tidak boleh memaksakan kehendaknya kepada siswa, tetapi guru membantu siswa untuk menentukan sikap ilmiah yang terdapat dalam diri siswa, serta mengembangkan sikap ilmiah yang dimiliki oleh siswa. Dengan demikian siswa akan leluasa dalam belajar, khususnya dalam pembelajaran matematika.

SMP Negeri 3 Minasatene dalam pembelajaran matematika guru selalu memberikan kepercayaan kepada siswa untuk mengembangkan idenya dalam menemukan sebuah rumus, guru juga mengajak siswa untuk selalu bersikap jujur kepada siswa dalam mengerjakan ulangan ataupun ujian, serta mengajarkan siswa untuk selalu mengevaluasi hasil pekerjaannya. Dengan demikian siswa selalu kesempatan untuk mengembangkan sikap ilmiahnya. Hal tersebut sangat mempengaruhi hasil belajar siswa dalam mengerjakan soal khususnya meteri bangun ruang yang cukup signifikan.

Jadi semakin tinggi sikap ilmiah siswa dalam belajar matematika, maka hasil belajar matematika semakin baik pula. Sebaliknya semakin rendah sikap ilmiah siswa dalam belajar, maka hasil belajar siswa semakin menurun.

\section{Penutup}

Berdasarkann kejian teori dari penelitian yang telah dilaksanakan untuk membahas sikap ilmiah terhadap hasil belajar dalam materi bangun ruang pada siswa kelas VIII SMP Negeri 3 Minasatene dapat disimpulkan sebagai berikut: 1) Ada pengaruh yang positif sikap ilmiah terhadap hasil belajar dalam materi bangun ruang kelas VIII SMP Negeri 3 Minasatene; dan 2) Besar pengaruh sikap ilmiah terhadap hasil belajar dalam materi bangun ruang dengan rataan kuadrat regresinya 21,366 sedangkan jumlah kuadrat sisanya adalah 31,843 sehingga kuadrattotalnya adalah 53,179 dengan fungsi tafsiran $Y=2.497+0,94 X$.

\section{DAfTAR PUStaka}

Ainurrahman. 2006. Belajar Dan Pembelajaran: Direktorat Jenderal Pendidikan Tinggi Departemen Pendidikan dan Kebudayaan. Bandung: Alfabeta. 
Amin, Suyitno. 2012. Penilaian IImiah dalam Pembelajaran Sains. Jakarta: Jurnal Pelangi IImu.

Anwar, Herson. 2009. Penilaian IImiah dalam Pembelajaran Sains. Jakarta: Jurnal Pelangi Ilmu.

Anni, Catharina Tri. 2005. Psikologi Pendidikan. Semarang: UPTK MKK UNNES.

Arikunto, Suharsimi. 2006. Prosedur Penelitian. Jakarta: Rineka Cipta.

Daryanto. 2010. Belajar dan Mengajar. Bandung: Yrama Widya.

Dimyati \& Mujiono. 2006. Belajar dan Pembelajaran. Jakarta: PT. Rineka Cipta.

Handini, Isriani. 2012. Strategi Belajar Pembelajaran Terpadu. Yogyakarta: Familia.

Huda, Miftahul. 2011. Condition of Learning. Surabaya:

Irianto, Agus. 2013. Statistik Konsep Dasar Aplikasi dan Penerapannya. Jakarta:

Mudzakar, Ahmad dan Jiko Sutrisno. 2009. Psikologi Pendidikan. Jakarta: Pustaka Setia.

Rusmono. 2012. Strategi Pembelajaran

Dengan Problem Based Learning. Jakarta.

Sudjana. 2011. Metode Statistik. Bandung:

Tarsito

Sukino. 2006. Matematika untuk SMP Kelas VIII. Jakarta: Erlangga

Sukino. 2006. Matematika untuk SMP Kelas XI. Jakarta: Erlangga

Trianto. 2009. Mendesain Model Pembelajaran Inovatif-Progresif.
Surabaya: PT Fajar Interpratama Mandiri.

\section{Riwayat HidUP PENULIS}

Firdha Razak, S.Pd. M.Pd.

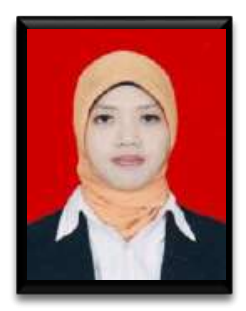

Lahir di Pangkajene, 22 Mei 1989. Staf pengajar di STKIP Andi Matappa Pangkep. Studi : S1 Pendidikan Matematika di STKIP Andi Matappa, Pangkep tahun 2007 dan lulus tahun 2011; S2 Pendidikan Matematika di Universitas Negeri Makassar pada tahun 2012 dan lulus tahun 2014. Tahun 2017 mendapat Hibah Penelitian Dosen Pemula dari Ristekdikti dengan Judul "Analisis Tingkat Berpikir Siswa Berdasarkan Teori Van Hiele pada Materi Pokok Dimensi Tiga Ditinjau dari Gaya Kognitif Kelas XII SMA Negeri 1 Pangkajene". Tahun 2017 menjadi pembicara/penyaji makalah dalam pertemuan Ilmiah Seminar Nasional Universitas Cokroaminoto Palopo dan pertemuan ilmiah Seminar Internasional " $2^{\text {nd }}$ ICSMTR 2017"

\section{Rahmat Kamaruddin, S.Pd. M.Pd.}

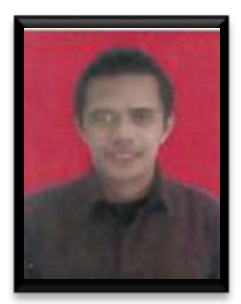

Lahir di Sinjai, 29 Jani 1986. Staf pengajar di STKIP Andi Matappa Pangkep. Studi : S1 Pendidikan Matematika di Universitas Negeri Makassar, tahun 2005 dan lulus tahun 2009; S2 Pendidikan Matematika di Universitas Negeri Makassar pada tahun 2011 dan lulus tahun 2013. Tahun 2017 mendapat Hibah Penelitian Dosen Pemula dari Ristekdikti dengan Judul "Pengembangan Perangkat Pembelajaran Matematika Materi Geometri Berbasis Teori Belajar Van Hiele untuk Pengembangan Pendidikan Karakter". Tahun 2017 menjadi pembicara/penyaji makalah dalam pertemuan Ilmiah Seminar Nasional Universitas Cokroaminoto Palopo dan pertemuan ilmiah Seminar Internasional " $2^{\text {nd }}$ ICSMTR 2017". 